\title{
Correlation between the state of periodontal tissues and selected cardiovascular parameters in patients with type 2 diabetes
}

\author{
MAGDALENA NAPORA, EWA GANOWICZ, RENATA GORSKA
}

Medical University of Warsaw, Poland

\begin{abstract}
Introduction: Type 2 diabetes and periodontitis are chronic diseases with a two-way interrelationship. Periodontitis is a chronic inflammatory disease increasing the risk of cardiovascular complications.

Aim of the study: To assess the impact of the state of periodontal tissues on selected cardiovascular parameters in patients with type 2 diabetes.

Material and methods: The study included 84 patients with type 2 diabetes who were treated at the Clinical Department of Internal Diseases, Endocrinology and Diabetology, Central Clinical Hospital of the Ministry of Interior in Warsaw. The patients had the following parameters determined: periodontal pocket depth, clinical attachment loss, plaque index, bleeding index, IMT, LVMI and systemic arterial pressure.

Results: The periodontal status of patients treated for type 2 diabetes was unsatisfactory, high values of periodontal parameters were observed. In a follow-up observation after one year, the clinical condition of periodontium was significantly deteriorated. There were correlations between the number of teeth and clinical attachment loss on the one hand and IMT on the other hand $(p<0.05)$.

Conclusions: Periodontitis in patients with type 2 diabetes may impact an increase of IMT (intima-media thickness), which confirms the association between periodontitis and cardiovascular diseases.
\end{abstract}

Key words: periodontitis, diabetes mellitus, cardiovascular diseases.

(Centr Eur J Immunol 2013; 38 (4): 556-561)

\section{Introduction}

Periodontitis is a chronic infectious disease of the oral cavity resulting in destruction of the tissues surrounding the tooth. The main cause of periodontal disease development is dental plaque. As a result of interaction between bacteria contained in the plaque and the host's tissues, an immune-inflammatory process begins, during which inflammatory mediators are released into the bloodstream. They are supposed to recruit the body's immune cells, drawing them to the front line of the bacterial infection. However, many of them operate in a non-specific way, and ultimately also affect the development and course of other diseases.

Particularly high levels of proinflammatory cytokines, characteristic of periodontal disease, are observed in patients with type 2 diabetes mellitus. Type 2 diabetes is a group of metabolic diseases characterized by hyperglycemia resulting from a defect in insulin secretion or action. Chronic hyperglycemia in diabetes is associated with dam- age, function disorder and, consequently, failure of various organs. Currently, it is believed that there is a two-way relationship between periodontitis and type 2 diabetes [1, 2]. Inflammatory mediators produced locally in periodontal tissues and secreted into the bloodstream affect the course of diabetes, reducing the effects of insulin on cells. As a result, hyperglycemia occurs. On the other hand, hyperglycemia leads to accumulation of glycoproteins that stimulate secretion of IL-6, TNF- $\alpha$ inflammatory mediators, causing destruction of periodontal tissues. In the course of diabetes, lesions develop in distant tissues and organs. The most common complications of type 2 diabetes include diseases of the eyes, kidneys, nerves, heart and blood vessels - the mechanism that leads to them are lesions within small and large blood vessels. Now, also periodontitis is considered one of the complications of type 2 diabetes.

Periodontitis, as an infectious disease, can also cause and intensify the inflammatory process in the wall of blood

Correspondence: Magdalena Napora, Department of Oral Mucosa and Periodontal Disease, Medical University of Warsaw, Miodowa 18, 00-246 Warsaw, Poland, tel. +48 2250220 36, e-mail: sluzowki@wum.edu.pl 
vessels and can contribute to the development of atherosclerosis and cardiovascular diseases. Bacterial species characteristic of periodontitis were identified in atherosclerotic plaque [3]. Elevated levels of cytokines, particularly IL-6 and TNF- $\alpha$, are observed in the course of cardiovascular diseases associated with atherosclerosis, type 2 diabetes mellitus and also in the course of periodontitis [4]. For these diseases, there is also a common group of risk factors such as age, gender, tobacco smoking, stress, and obesity.

The mentioned diseases are common among the population. It is believed that they are somehow interrelated. Due to the complex nature of each of them, and to local and generalized phenomena developing in their course, research on these relationships is difficult and most researchers are limited to populations with only two concomitant diseases.

Until now it has not been clearly explained if periodontitis in patients with type 2 diabetes may impact the condition of the cardiovascular system and additionally modify cardiac parameters. The present work is a continuation of a series of studies on the relationship between periodontitis and systemic diseases.

\section{Aim of the study}

Assessment of the relationship between the state of periodontal tissues and selected cardiovascular parameters in patients with type 2 diabetes.

\section{Material and methods}

The study included patients with diagnosed type 2 diabetes who were treated at the Clinical Department of Internal Diseases, Endocrinology and Diabetology, Central Clinical Hospital of the Ministry of Interior in Warsaw. From among randomly selected 250 patients, only individuals with at least seven natural teeth were qualified. In this way 119 patients were included in the study (67 males and 52 females), median age was 62 years (age range 39-82 years). The median duration of type 2 diabetes was 8 years (range from 1 to 27 years).

Eighty four individuals out of the 119 examined reported to the follow-up after one year $(70.6 \%$ of the group taking part in the first study), including 49 males (58.3\%) and 35 females $(41.7 \%)$. Median age of the study group was 62.5 years (age range 39-77 years).

Statistical analysis included only those patients who participated in the first and second examinations (84 individuals)

The examinations were conducted in the form of a two-week block at the Clinical Department of Internal Diseases, Endocrinology and Diabetology, Central Clinical Hospital of the Ministry of Interior in Warsaw. On the same day, each patient underwent a general medical and periodontal examination. It was repeated after one year using the same procedure.
The patients had basic periodontologic measurements taken. The plaque index (PI) by O'Leary was rated on four surfaces of the tooth (mesial, midline buccal, distal, midline palatal/lingual) with the WHO-621 probe. The periodontal pocket depth (PD), clinical attachment loss (CAL) and bleeding index (BOP) by Ainamo and Bay were calculated by measurements on six surfaces of the tooth.

Using echocardiography, the following parameters were determined: thickness of tunica intima and tunica media of the intima-media complex of the carotid artery (IMT), left ventricular mass LVM and left ventricular mass index LVMI. The LVMI value was obtained by dividing LMV by the body surface area (calculated on the basis of height and body weight). Systemic blood pressure was also measured. The mean blood pressure value was obtained from three measurements taken while the patient was in a resting position.

The study was conducted in accordance with the Helsinki Declaration of 1973, updated in 2002, and it was endorsed by the Bioethics Committee. All the patients made themselves acquainted with an information form and signed their consent to the study. They were also instructed on oral hygiene and recommended periodontal treatment. All patients remained under diabetes care provided by the Central Clinical Hospital of the Ministry of Interior.

The obtained data were analyzed statistically using the PQStat package with Wilcoxon test for related groups and the Mann-Whitney test for unrelated groups and Spearman's correlation test. The threshold for statistical significance was set at $p<0.05$.

\section{Results}

Table 1 shows the general characteristics of the study group in terms of cardiac parameters in the first and second examinations. In the study group, the mean values of cardiac parameters were within normal range for laboratory tests, however they were close to the upper limits. Hypertrophy of the left ventricular mass is observed when LVMI for females $\geq 125 \mathrm{~g} / \mathrm{m}^{2}$ and when LVMI for males $\geq 110 \mathrm{~g} / \mathrm{m}^{2}$. IMT $>0.9 \mathrm{~mm}$ precedes development of atherosclerotic lesions [5]. The follow-up study after one year showed an improvement in LVMI and IMT values, the differences were statistically significant.

Table 2 presents an analysis of the relationship between the clinical condition of the oral cavity and cardiovascular parameters: the left ventricular mass index LVMI, indicator of atherosclerosis severity IMT and blood pressure value. There was no statistically significant correlation between dental parameters on the one hand and the left ventricular mass index and blood pressure on the other hand. A negative correlation was observed between the number of natural teeth and IMT. More advanced atherosclerotic lesions were found in patients with a lower number of teeth and a lower number of periodontal pockets 
Table 1. Status of cardiac parameters at baseline and after one year

\begin{tabular}{lccc}
\hline Parameter & $\begin{array}{c}\text { Examination 1 } \\
\text { Mean value (SD) }\end{array}$ & $\begin{array}{c}\text { Examination 2 } \\
\text { Mean value (SD) }\end{array}$ & $\begin{array}{c}\text { Difference after one year } \\
\text { (Wilcoxon test) }\end{array}$ \\
\hline IMT & $0.77(0.13)$ & $0.79(0.14)$ & $\mathrm{ns}$ \\
\hline LVMI & $99.5(25.2)$ & $101.1(20.9)$ & $\mathrm{ns}$ \\
\hline BPs & $137.9(12.7)$ & $134.7(12.8)$ & $\mathrm{ns}$ \\
\hline BPd & $80.1(6.8)$ & $81.7(8.8)$ & $\mathrm{ns}$ \\
\hline
\end{tabular}

$>4 \mathrm{~mm}$. Our study also demonstrated a positive correlation between clinical attachment loss and the gingival bleeding index on one hand and the IMT value on the other hand. There was also a positive correlation between the plaque index and the value of systolic blood pressure.

\section{Discussion}

Type 2 diabetes is a disease that yields systemic complications of various degree, especially within the cardiovascular system. It is also associated with a higher incidence of periodontitis. Coexistence of periodontal disease in patients with type 2 diabetes may influence long-term control of diabetes, as demonstrated in studies by Khader et al. [6], and Benveniste et al. [7]. The authors indicated a correlation between periodontal parameters and the degree of glycemic control expressed by glycosylated hemoglobin levels, confirming the association of periodontal diseases with type 2 diabetes. In our study, such relationship between these disease entities was also confirmed [8].

The present study assessed the relationship between the state of periodontal tissues and selected cardiac parameters in patients with type 2 diabetes. The patients who took part in the study were under constant diabetes and cardiac care. The results of echocardiography and blood pressure were within the normal range, but close to the upper limit. The patients were subjected to general medical treatment as required. In a follow-up after one year, an improvement in cardiac parameters was observed. There was a statistically significant reduction in the value of the atherosclerosis severity indicator $(p<0.001)$.

The results of the periodontal examination were presented in detail in the previous publication in this cycle of study [8]. It should be mentioned that the periodontal status was unsatisfactory, with a high plaque index $(80.5$ $\pm 16 \%)$ and bleeding index $(26.8 \pm 13 \%)$, mean pocket depth was $2.8 \pm 0.7 \mathrm{~mm}$, and mean clinical attachment loss equaled $4.0 \pm 1.4 \mathrm{~mm}$.

The analysis showed a relationship between periodontal parameters and the selected cardiologic parameters, in particular the severity of atherosclerosis. This is confirmed by other authors who observed an association between periodontitis with cardiovascular diseases, as indicated, inter alia, in the studies by Persson et al. and Blaizot et al. [10, 11]. In our study, no statistically significant correlation was observed between the left ventricular mass

Table 2. Analysis of the relationship between the periodontologic and cardiac parameters (Spearman's test)

\begin{tabular}{|c|c|c|c|c|}
\hline Parameter & LVMI & IMT & BPs & BPr \\
\hline Number of teeth & ns & ns & $\begin{array}{c}r=-0.18 \\
p<0.1\end{array}$ & ns \\
\hline Mean PD & ns & ns & $\begin{array}{l}r=0.27 \\
p<0.05\end{array}$ & ns \\
\hline Median PD & ns & ns & ns & ns \\
\hline Number of pockets $\geq 4 \mathrm{~mm}$ & ns & $\begin{array}{c}r=-0.21 \\
p=0.05\end{array}$ & $\begin{array}{c}r=0.19 \\
p<0.1\end{array}$ & ns \\
\hline Number of pockets $\geq 4 \mathrm{~mm}$ with bleeding & ns & ns & ns & ns \\
\hline Mean CAL & ns & ns & ns & ns \\
\hline Median CAL & ns & ns & ns & ns \\
\hline PI & $\mathrm{ns}$ & $\begin{array}{c}r=0.19 \\
p<0.1\end{array}$ & $\begin{array}{c}r=0.37 \\
p<0.001\end{array}$ & $\begin{array}{c}r=0.35 \\
p=0.001\end{array}$ \\
\hline BI & ns & ns & $\begin{array}{l}r=0.23 \\
p<0.05\end{array}$ & $\begin{array}{l}r=0.24 \\
p<0.05\end{array}$ \\
\hline
\end{tabular}


index and periodontal parameters. In the study by Frank et al. [12], the authors assessed the condition of periodontal tissues according to Offenbacher scale. Patients diagnosed with periodontal disease demonstrated a higher rate of LVMI compared to healthy subjects. Also, the study by Ganowicz et al. [13] indicated that patients with periodontitis are expected to have a more severe left ventricular hypertrophy.

In our own study, a negative correlation between the number of natural teeth and the severity of atherosclerosis was observed. In individuals with fewer teeth, the IMT value was higher. This may indicate a past ongoing inflammatory process in periodontal tissues, including marginal and periapical periodontium (complications of pulp diseases), which had an effect on the condition of blood vessels and development of atherosclerotic plaque. Further development of periodontitis affected the severity of atherosclerosis. A consequence of progressive periodontal disease and lack of periodontal treatment is loss of teeth. Numerous missing teeth suggest that the patients in this study did not attach much significance to prevention and dental treatment, solving dental problems by means of tooth extractions. Similar results were obtained by Paunio et al. [14], who in a group of 1384 males observed twice as frequent incidence of coronary heart disease in individuals with less than half remaining teeth.

Our own study demonstrated a positive correlation between clinical attachment loss and severity of atherosclerosis. A higher value of clinical attachment loss indicates advanced periodontal disease and is a summary indicator of the current course of the disease, because spontaneous regeneration of the attachment is infrequent. Therefore, it may be concluded that higher clinical attachment loss means for the patient, a longer or stronger exposure to the markers of inflammation, bacterial toxins, and any other compounds released in the course of periodontitis. In the study group, patients with advanced periodontitis demonstrated also more advanced atherosclerotic lesions. Similar results were obtained by Frank et al. [15], who observed a relationship between periodontal disease and the severity of atherosclerosis. A clinical trial by Włosowicz [16], conducted among patients hospitalized due to ST segment elevation myocardial infarction and non-ST segment elevation myocardial infarction, also indicated a significantly thicker IMT in the group with advanced periodontal disease compared to the group with mild periodontitis. The author observed a significantly higher value of intima-media thickness in edentulous patients. A study by Desvarieux et al. [17] demonstrated a relationship between the number of missing teeth and presence of atherosclerosis in the carotid artery. Progressive periodontal tissue inflammation and clinical attachment loss lead to loosening and loss of teeth. Presence of inflammatory markers and periopathogens at this time can affect the development of atherosclerotic lesions. Lack of teeth may be a marker of past periodontitis which during its course initiated the development of subclinical atherosclerosis. Such a relationship is also confirmed by the results of research conducted by Zaremba et al. [18], in which the authors observed the presence of bacteria typical of periodontitis in atherosclerotic plaque in both toothed and edentulous subjects.

In our study, a statistically significant correlation ( $p=0.01$ ) between bleeding of gingiva and thickness of the intima-media complex was observed. Bleeding is one of the primary symptoms of inflammation currently ongoing in periodontium. In a study carried out by Frank $e t$ al. [15], a higher IMT was observed in BGI-P2 patient group compared with BGI-P1 patient group according to

Table 3. Analysis of the relationship between the periodontologic parameters and cardiovascular system status in one-year follow-up (Spearman's test)

\begin{tabular}{|c|c|c|c|c|}
\hline Parameter & LVMI & IMT & BPs & BPr \\
\hline Number of teeth & ns & $\begin{array}{l}r=-0.26 \\
p<0.05\end{array}$ & ns & $\begin{array}{c}r=-0.20 \\
p<0.1\end{array}$ \\
\hline Mean PD & ns & ns & ns & ns \\
\hline Median PD & ns & ns & ns & ns \\
\hline Number of pockets $\geq 4 \mathrm{~mm}$ & ns & ns & ns & ns \\
\hline Number of pockets $\geq 4 \mathrm{~mm}$ with bleeding & ns & ns & ns & ns \\
\hline Mean CAL & ns & $\begin{array}{l}r=0.24 \\
p<0.05\end{array}$ & ns & ns \\
\hline Median CAL & ns & $\begin{array}{l}r=0.24 \\
p<0.05\end{array}$ & ns & ns \\
\hline PI & ns & $\mathrm{ns}$ & $\begin{array}{l}r=0.22 \\
p<0.05\end{array}$ & $\begin{array}{l}r=0.19 \\
p<0.1\end{array}$ \\
\hline BI & ns & $\begin{array}{l}r=0.25 \\
p<0.05\end{array}$ & $\mathrm{~ns}$ & ns \\
\hline
\end{tabular}


Offenbacher classification. The BGI-P2 group demonstrated periodontal pocket depth $\mathrm{PD} \geq 4 \mathrm{~mm}$ and bleeding index BOP 10-50\%. Higher IMT was observed in patients with an elevated level of the bleeding index. In a study by Söder et al, higher IMT was characteristic of patients with the elevated bleeding index. In patients with gingivitis and periodontitis the authors observed a significantly higher IMT value, compared with patients without inflammation within periodontal tissues [19]. Emingil et al. demonstrated a correlation between periodontal tissue inflammation and advanced atherosclerotic lesions of the cardiovascular system leading to acute myocardial infarction (AMI). The authors found a relationship between the bleeding index and periodontal pocket depth $\geq 4 \mathrm{~mm}$ on the one hand and the occurrence of acute myocardial infarction on the other hand [20].

Different results were obtained by Lopez-Jornet et al. [21]. The authors found no statistically significant correlation between the bleeding index and the severity of atherosclerosis (expressed by IMT). Analyzing the relationship between the bleeding index and presence of atherosclerotic plaque, the authors found no significant correlation between presence or absence of plaque and the bleeding index.

Cario et al. suggest the presence of subclinical atherosclerosis in patients with periodontitis [22]. Also a study conducted by Beck et al. confirmed an association between periodontitis and thickness of the intima-media complex [23]. The authors observed a higher IMT value in patients with periodontal disease.

In our study, no statistically significant correlation between periodontal parameters and the value of systemic blood pressure was observed. There was only a statistically significant relationship between the plaque index and the value of systolic blood pressure. A high plaque index may indicate presence of many species of bacteria in periodontal pockets. According to the specific bacterial plaque theory, presence of periopathogens can be expected in bacterial plaque. This may suggest an existing link between bacteria typical of periodontitis and atherosclerosis progression with narrowing of the arteries, leading to an increase in systemic pressure. Research by Desvarieux et al. [24] indicated a direct relationship between the level of bacteria in subgingival plaque and arterial hypertension.

A study by Selvin et al. showed that diabetes and its associated metabolic misalignment are related to a high risk of cardiovascular diseases [25]. The risk is increased in patients with type 2 diabetes due to multiple risk factors: elevated levels of cholesterol and triglycerides, hypertension, smoking and obesity. One of complications of type 2 diabetes is periodontitis, which - as demonstrated in research by Janket - even in patients without concomitant systemic diseases may constitute a risk of developing diseases of the cardiovascular system [26].
In a study conducted on Pima Indians with type 2 diabetes and concomitant periodontitis, a higher risk of cardiovascular diseases and death was observed [27].

Therefore, it appears that periodontal disease may be an independent risk factor for cardiovascular diseases. Such a conclusion was reached in a study by Blaizot $e t$ al., however the direct influence of periodontitis on the condition of the cardiovascular system, was not explained [28].

The present work confirms an association between cardiovascular disease and periodontitis, also in population additionally burdened with type 2 diabetes. Particularly a correlation between past (CAL) and present (BOP) periodontitis and severity of atherosclerosis (IMT) was clearly demonstrated. Notably, this correlation is strong, despite subjecting the patients to treatment of systemic causative diseases.

The demonstrated correlations between periodontal and cardiac parameters once again draw attention to the need of providing special dental care to patients with type 2 diabetes. Even the underlying disease carries a risk of many serious complications. Adding an additional component, which is periodontitis, can lead to increased cardiovascular complications.

\section{References}

1. Preshaw PM, Foster N, Taylor JJ (2007): Cross-susceptibility between periodontal disease and type 2 diabetes mellitus: an immunobiological prespective. Periodontol 15: 138-152.

2. Genco RJ (1996): Current view on risk factors for periodontal disease. J Periodontol 67: 1041-1049.

3. Zaremba M, Górska R, Suwalski P, Kowalski J (2007): Evaluation of the incidence of periodontitis-associated bacteria in the atherosclerotic plaque of coronary blood vessels. J Periodontol 78: 322-327.

4. Czerniuk MR, Górska R, Filipiak KJ, et al. (2006): C-rective protein in patients with coexistent periodontal disease and acute coronary syndromes.J Clin Periodontol 33: 415-420.

5. Choroby wewnętrzne. Stan wiedzy na rok 2011. Szczeklik A (red.). Medycyna Praktyczna, Kraków 2011.

6. Khader YS, Dauod AS, El-Quaderi SS, et al. (2006): Periodontal status of diabetics compared with nondiabetics: a meta-analysis. J Diabetes Complications 20: 59-68.

7. Benveniste R, BiXler D, Conneally PM (1967): Periodontal disease in diabetics. J Periodontol 38: 271-279.

8. Napora M, Ganowicz E, Górska R (2012): Analiza zależności między stanem klinicznym przyzębia a stopniem kontroli cukrzycy typu 2 - badanie wstępne. Dent Med Probl 49: 377-382.

9. Morton AA, Williams RW, Watts T (1995): Initial study of periodontal status in non-insulin dependent diabetics in Mauritius. J Dent 23: 343-345.

10. Persson GR, Persson RE (2008): Cardiovascular disease and periodontitis;an update on the associations and risk. J Clin Periodontol 35: 362-379.

11. Blaizot A, Vergnes JN, Nuwwareh S, et al. (2009): Periodontal disease and cardiovascular events: metaalalysis of observational studies. Int Dent J 2009; 59: 197-209. 
12. Franek E, Napora M, Blach A, Budlewski T, Gozdowski D, Jedynasty K, Krajewski J, Gorska R (2010): Blood pressure and left ventricular mass in subjects with type 2 diabetesand gingivitis or chronic periodontitis. J Clin Periodontol 2010; 37: 875-880.

13. Ganowicz E, Bach A, Klamczynska E, et al. (2007): Choroby przyzębia jako czynnik modyfikujący wpływ innych czynników ryzyka na rozwój przerosty lewej komory serca. Dent Med Probl 47: 47-52.

14. Paunio K, Impivaara O, Tiekso J, et al. (1993): Missing teeth and ischemic heart disease in men aged 45-64 years. Eur Heart J 14: 54-56.

15. Franek E, Januszkiewicz-Caulier J, Błach A, et al. (2012): Intima-media thickness and other markers of atherosclerosis in patients with type 2 diabetes and periodontal disease. Kardiol Pol 70: 7-13.

16. Włosowicz M. (2011): Stan jamy ustnej a występowanie i przebieg zawału serca w fazie szpitalnej. Praca doktorska, Warszawa 2011.

17. Desvarieux M, Demmer RT, Rundek T, et al. (2003): Relationship between periodontal diseasea, tooth loos and corronary artery plaque: the Oral and Vascular Disease Epidemiology Study (INVEST). Stroke 34: 2120-2125.

18. Zaremba M, Górska R, Suwalski P (2005): Ocena występowania bakterii związanych $\mathrm{z}$ chorobą przyzębia w blaszce miażdżycowej naczyń wieńcowych. Czas Stomat 58: 5.

19. Söder B, Yakob M, Nowak J, Jogestrand T (2007): Risk for the development of atherosclerosis in women with a high amount[corrected] of dental plaque and severe gingival inflammation. Int J Dent Hyg 2007; 5: 133-138.

20. Emingil G, Buduneli E, Aliyev A, Akilli A, Atilla G (2000): Association between periodontal disease and acute myocardial infarction. J Periodontol 71: 1882-1886.

21. Lopez-Jornet P, Berna-Mestre JD, Berna-Serna JD, et al. (2012): Measurement if atherosclerosis markers in patients with periodontitis:a case-control study. J Periodontol 83: 690698.

22. Cario F, Castellani S, Gori AM, et al. (2008): Severe periodontitis in young adults is associated with su-clinical atherosclerosis. J Ciln Periodontal 35: 465-472.

23. Beck JD, Elter JR, Heiss G, et al. (2001): Relationship of periodontal disease to carotid artery intima-media wall thickness; the atherosclerosis risk in communities (ARIC) study. Arterioscler Thromb Vasc Biol 21: 1816-1822.

24. Desvarieux M, Demmer RT, Jacobs DR Jr, et al. Periodontal bacteria and hypertension: the oral infections and vascular disease epidemiology study (INVEST). J Hypertens 2010; 28: 1413-1421.

25. Selvin E, Marinopoulos S, Berkenblit G, et al. (2004): Meta-analysis: glycosylated hemoglobin and cardiovascular disease in diabetes mellitus. Ann Intern Med 141: 421-431.

26. Janket SJ, Baird AE, Chuang SK, Jones JA (2003): Meta-analysis of periodontal disease and risk of coronary heart disease and stroke. Oral Surg Oral Med Oral Pathol Oral Radiol Endod 2003; 95: 559-569.

27. Saremi A, Nelson RG, Tulloch-Reid M, et al. (2005): Periodontal disease and mortality in type 2 diabetes. Diabetes Care 28: 27-32.

28. Blaizot A, Vergnes JN, Nuwwareh S, et al. (2009): Periodontal diseases and cardiovascular events: a meta-analysis of observational studies. Int Dent J 59: 197-209. 